\title{
CAMPAIGNING FOR LIFE: BUILDING A NEW TRANSNATIONAL SOLIDARITY IN THE FACE OF HIV/AIDS AND TRIPS
}

Heinz Klug

\subsection{INTRODUCTION}

In a dramatic display of political astuteness, six hundred volunteers under the banner of the Treatment Action Campaign, a non-government organization dedicated to ensuring access to treatment for the millions of South Africans infected with HIV/AIDS, commemorated human rights day in South Africa in 2003 by marching on the same police station at Sharpeville where anti-apartheid protestors had been gunned down on March 21, 1960. Symbolizing the number of South Africans dying each day from HIV/AIDS-related illnesses, the demonstrators demanded that the government immediately agree to establish an antiretroviral treatment program in the public health sector. At the same time, fellow TAC protestors in Durban and Cape Town highlighted the urgency of their demands by laying formal charges of culpable homicide against the Minister of Health as well as the Minister of Trade and Industry whom they accused of negligently failing to act and thus of causing the deaths of thousands of AIDS sufferers.

This campaign reflects a situation in marked contrast to the day nearly a decade before in May 1994, when Nelson Mandela, in his first official exercise of power as President of South Africa, announced that free health services must be provided to all children under the age of six and to pregnant women. Yet, unlike the over forty-year struggle against apartheid, within a year the government had conceded that the public sector must provide treatment and was instead embroiled in a debate over the pace of implementation of the promised program. While it is 
indeed sad, as the Reverend Douglas Torr, the Anglican priest who led the TAC marchers in prayer at Sharpeville told the crowd, "that those who fought to liberate South Africa from apartheid needed to fight again," this paper argues that this new social movement, built in the context of the HIV/AIDS pandemic and in response to the extreme disparities in access to affordable medicines, has provided the impetus for a new transnational solidarity which has important implications far beyond South Africa and the immediate struggle for treatment.

In his opening address to the 13th International AIDS Conference in Durban, South Africa, in July 2000, Judge Edwin Cameron of the High Court of South Africa, claimed to embody in person "the injustice of AIDS in Africa." Cameron pointed out that he could live "only because, on a continent in which 290 million Africans survive on less than one US dollar a day, I can afford medication costs of about $\$ 400$ per month." Accusing manufacturers of imposing prices which made drugs "unaffordably expensive," Cameron noted that the international patent and trade regime prevents the production and marketing of affordable drugs - despite earlier experience in India, Thailand, and Brazil, which he argued demonstrates the feasibility of producing key drugs at costs that would be within reach of the developing world. Yet the global brand-name pharmaceutical industry seemed to remain deaf to these arguments and continued to insist that the cost of patented drugs is directly proportional to their research and development expenditures which they argue guarantee the innovation necessary to produce future generations of miracle drugs. However, a growing movement of solidarity between HIV/AIDS activists, and health, consumer, and development-oriented NGOs, as well as cooperation among developing countries in international fora, brought increasing pressure to bear on both the companies and first world governments, leading over a four-year period to a dramatic reduction in the international prices of HIV/AIDS medications, including antiretroviral therapies.

The international framework for patent rights evolved rapidly in the late twentieth century. Historically, the protection of patent rights, while pursued internationally through the adoption of international agreements, was fundamentally a prerogative of national sovereignty. In fact, before the issue was put on the agenda at the Uruguay Round of trade talks in 1986, approximately forty states did not issue patents for pharmaceuticals, leading in some countries to a proliferation of copies of patented drugs. At the international level, the Paris and Berne Conventions impose only very general rules guaranteeing national 
treatment, but not the protection of all intellectual property rights. The international regime of intellectual property protection prior to 1994 provided no guarantee of protection for intellectual property-intensive industries; instead, its protection depended upon the rights each jurisdiction offered its own citizens. Switzerland, for example, benefited from participation in the Paris Convention yet refused to issue patents domestically until 1887 . This ensured that Swiss corporations received the same protection for their intellectual property rights as local companies in other member states, yet Switzerland provided no protection of patent rights in its territory at all. So long as both Swiss and foreign corporations were denied protection equally, Switzerland remained true to its obligations under the treaty (Moy 1993). In other cases, such as India, patent law distinguished between different sectors and in the case of pharmaceuticals provided only process and not product patents, thus enabling generic manufacturers to reverse engineer patented drugs and legitimately produce the same product so long as they worked out a different production process. It was in this context that the intellectual property-intensive industries sought some minimum protection of their rights, and in the negotiations over TRIPS focused on creating a new international regime (see Ryan 1998; Sell 2003).

Despite adoption of the 1970 Patent Cooperation Treaty, increasing the World Intellectual Property Organization's (WIPO) institutional capacity to provide technical support services to national patent offices, the pharmaceutical industry continued to complain about commercial losses they attributed to the weakness of intellectual property rights protection, particularly in newly industrializing countries. For the pharmaceutical industry the goal was the establishment of minimum standards of patent protection allowing the increasingly multinational corporations that dominate the industry to operate in a single global market. The minimum standards now recognized under TRIPS represent important gains for the industry, including: an extended period of protection - to twenty years; the requirement that all technologies receive equal treatment - precluding lesser protection for pharmaceuticals; and limits on compulsory licensing.

For the brand-name industry, however, this is just the beginning as they continue to strive for what is often termed TRIPS-plus. These goals include: a complete ban on compulsory licensing and parallel imports; pipeline protection for inventions still under development; 
no early registration or stockpiling of generics prior to the termination of the patent period; and liberal rules allowing for patent extension. While the pharmaceutical companies assert that the protection of their intellectual property rights is an essential prerequisite to the continuing development of life saving drugs, the reality for the majority of people around the world is that they cannot afford to enter the private market and instead rely on their national public health services to address their health needs.

It is the tension between specific local needs, in this case the need to provide access to affordable medicines, and the international commitments developing countries must make in order to participate in the global economy that highlights the significance of the struggle to reconstitute international solidarity. Bringing together civil society, developing country governments as well as international nongovernmental organizations, this new movement aims both to pressure states and to empower them to demand a rebalancing of the social needs of their citizens and the claims of "economic globalization." Using the case of South Africa's need to obtain affordable medicines and surveying the international debate over the interpretation of the TRIPS agreement, this paper will argue that the emergence of a global HIV/AIDS pandemic has fundamentally transformed the context within which this debate is being carried out.

Furthermore, I will argue that the struggle over access to affordable medicines is providing an hospitable arena within which to demand a reasonable balance between social needs and claims based on the assertion of property rights. While demands for access to medicines are empowered by the emergence of a new social movement in the face of the HIV/AIDS pandemic, producing major concessions from both the global pharmaceutical industry and developed countries such as the United States, these concessions have thus far been limited to voluntary price reductions and agreement on a highly complex exception to the limitations on compulsory licensing contained in TRIPS. Changes, both at the domestic level in response to social activism and at the international level, provide examples of how increased solidarity between social movements across the world and between developing countries, may achieve the desperately needed reconfiguration of, on the one hand, the social needs of citizens, which can only be adequately addressed by the provision of public goods, and, on the other hand, the demands of private rights claimants who rely on public guarantees of their property to exercise market power. 


\subsection{CHANGING THE FACE OF SOUTH AFRICA}

South Africa's democratic transition was marked by the embrace of constitutionalism as a means of both facilitating and guaranteeing the creation and consolidation of a democratic state (Klug 2000). Given a history of racially structured deprivation the African National Congress (ANC) recognized that a commitment to constitutionally enshrined civil rights would merely entrench the economic distributions of apartheid unless supplemented by a commitment to at least the basic guarantees of socio-economic rights. In addition to these constitutional commitments, the new government began to implement its Reconstruction and Development Programme (RDP)on which it had campaigned for election. The essence of the RDP was a strategy to achieve economic growth and development through the redistribution of social resources. The RDP thus contained the dual goals of seeking to address the basic inequalities in social distribution legally enshrined by apartheid as well as promoting policies geared toward economic expansion which would be key to absorbing the vast numbers of unemployed and underemployed people who had been marginalized during the apartheid era.

In the health sector, the RDP immediately established a Presidential lead project to provide free health services to children under six and pregnant women, while the ANC's National Health plan envisaged a broader goal of making "basic health care available to all South Africans, giving priority to the most vulnerable groups." Emphasizing "[m]aternal and child care, the protection of the environment, services in the rural areas, women's health and the care of the disabled," the plan also promised that there would be "a focus on the prevention and control of major risk factors and diseases, especially AIDS, tuberculosis, measles, gastro-intestinal disease, trauma, heart disease and common cancers" (ANC 1994b). This policy process was capped with the adoption of the "final" 1996 Constitution which guarantees, among other socio-economic rights, the right to have access to "health care services" (section 27(1)(a)).

Introducing a constitutional right to health in a context of vast inequality and limited resources soon produced a tragic but classic confrontation between the health authorities and a patient who required access to renal dialysis in order to prolong his life. When the case Soobramoney, reached the Constitutional Court in 1997, the court drew a distinction between the right not to be refused emergency 
medical treatment in terms of section 27(3) and the progressive realization of the right to health care guaranteed in section 27(1). Rejecting Soobramoney's claim of a right to receive treatment, the Constitutional Court in effect recognized that certain medical decisions - in this case the decision to limit access to those patients whose medical condition made them eligible to receive kidney transplants are best made by medical personnel and should not be second-guessed by the courts.

Subsequently, in a challenge to the government's limited provision of Nevirapine to prevent mother-to-child transmission of HIV (TAC, 2001), the Constitutional Court rejected the government's attempt to draw an analogy between the "medical decision" in Soobramoney and the question of whether Nevirapine should be made available beyond the eighteen test sites established by health authorities. While the medical status of individuals who need kidney transplants is clearly a medical question, the court held that the issue of whether public sector doctors may prescribe a registered drug where medically indicated is not. Even if the relationship between the availability of donated kidneys and the possibility of a successful transplant, as determined by the health of the donee, may be considered a medical question, the issue of whether it makes sense to provide a particular patient or group of patients with a particular treatment is not solely a medical judgment. Where the public sector is failing to provide a particular treatment regime, medically indicated and available in the private sector, then the issue is clearly one of health policy and resources and thus implicates the progressive realization of the right to health care services. The court's decision to require the government to extend the provision of Nervirapine throughout the public health system represented a major success for civil society and legal strategies to enforce socio-economic rights.

\subsection{THE PHARMACEUTICAL SECTOR AND THE STRUGGLE FOR AFFORDABLE MEDICINES}

The structure of South Africa's pharmaceutical industry as well as the pharmaceutical supply system is particularly marked by the legacy of apartheid. While the industry is dominated by subsidiaries of the multinational pharmaceutical corporations, the market this industry is geared to serve reflects the apartheid divide. Although the highest value for the industry lies in supplying the small, predominately 
white, middle class who are served by the private health system, the vast bulk of drugs produced are distributed through the public health system. Yet this latter segment represents only a fraction of the value of the industry's sales, since the government purchases in bulk and obtains substantial discounts from the manufacturers.

Thus, although pharmaceutical firms made only a small profit on the supply of drugs to the public system, they were able to charge relatively high prices to private consumers. While the high cost of drugs in the private market might have been mediated by the introduction of generics, the very structure of the South African market discouraged generic drug manufacturers from entering the market. Brand manufacturers thus provided the bulk of the drugs consumed in the country, either to the public sector at close to generic prices, or directly to the private market. While this bifurcated structure of the pharmaceutical market reflected the old apartheid system, where the majority of those served by the public sector had little or no political power, the new government's goal of broadening access to health care by integrating the public and private health care systems changed this equation. This is particularly the case in relation to the supply of medicines: the goal of improving standards through the creation of a greater public-private partnership tied to ideas of equalization and cross-subsidization through some form of social or national health insurance program based on the goal of sharing costs - possibly including a more extensive system of copayments - makes the cost of medicines in the marketplace a central concern to the new system.

In response to this situation, the new government published a National Drug Policy in January 1996. As a way of attacking the comparatively high cost of drugs in the South African market, the new policy promoted the use of generic drugs and suggested several ways to reduce unacceptably high retail prices, including allowing the state to facilitate the availability of affordable drugs in the private sector. It was this policy imperative that led to the passage of the Medicines and Related Substances Control Amendment Act in December 1997 (Act 90 of 1997), with the aim of bringing down the cost of medicines. Although the new Act was designed to fundamentally change the distribution practices of the pharmaceutical manufacturers - prohibiting, for example, industry employees from serving on the Medicines Control Board, and blocking manufacturers and wholesalers from providing bonuses, rebates, or other incentives to doctors the key feature of the Act was the "measures to ensure supply of more 
affordable medicines." These measures included empowering the Minister of Health "to prescribe conditions for the supply of more affordable medicines .... so as to protect the health of the public ... notwithstanding anything to the contrary in the Patents Act," and to "prescribe the conditions on which any medicine which is identical in composition, meets the same quality standard and is intended to have the same proprietary name as that of another medicine already registered in the Republic," may be provided. The effect of these provisions would have been to allow the parallel importation of medicines, generic substitution without the consent of the prescriber, and even compulsory licensing.

While the amendments to the Medicines Act were initially viewed as a simple adoption of World Health Organization (WHO) recommended measures to improve access to essential medicines, the changing health conditions as well as the growing international conflict over the implementation of TRIPS and the expanded protection of patent rights suddenly placed these reforms under the international spotlight. At the same time, the new government's changing economic policies, from a domestic focus on reconstruction to a focus on global reengagement, including a full embrace of the World Trade Organization (WTO) and TRIPS, heightened the sensitivity of the government to external pressure, particularly when these pressures seemed to directly threaten the policy of attracting foreign capital and increasing industrial capacity domestically as a means of supplying the regional or even the continental market. These changing circumstances were further intensified by the recognition in 1996 that antiretroviral therapies had the potential to dramatically transform the profile of the HIV/AIDS pandemic from a death sentence to a chronic but manageable illness. The simultaneous advent of these developments, including changes in economic policy and law as well as the exploding HIV/AIDS epidemic, set the stage for a protracted confrontation with ramifications in both the domestic and the international arenas.

\subsection{GLOBAL COMMITMENTS AND DOMESTIC RESPONSES}

During the final stages of South Africa's negotiated transition to democracy, the African National Congress agreed to join the government's delegation participating in the Marrakech Conference which concluded the Uruguay Round of multilateral trade negotiations. 
South Africa, long excluded from international multilateral meetings, signed the treaty (WTO 1994) creating the WTO, and accepted the TRIPS agreement, on April 15, 1994. Thus, while April 1994 marks the moment of South African national self-determination, it also marked its reentry as an active participant in the international economic arena through its participation as a founding member of the WTO. As an official in the Department of Trade and Industry later remarked, "South Africa was a founding member of the GATT and would of course embrace all the obligations included in the new international trading system" (author's interview, Pretoria, 1999). Endorsing this self-image as a bastion of free trade, despite the very recent history of international sanctions against apartheid, the South African government, merely days before the country's first democratic elections, eschewed the special transitional provisions for developing countries and accepted the immediate implementation of the agreement. The advocates of free trade believed that this early adoption would enhance South Africa's comparative advantage at the moment it was reentering the global economy and hoped for a wave of post-apartheid foreign investment. However, it was precisely this enthusiasm, reflecting the general confidence of a successful political transition, which led the country to immediately embrace all the commitments of the WTO agreement, including those contained in TRIPS, and which soon embroiled the new government in its first major international controversy.

South Africa's attempt to improve access to essential medicines by creating a more competitive market by considering parallel importation and even compulsory licensing soon attracted the attention of the international pharmaceutical industry and the US government in particular (see Bond 1999). In fact, the US government was active in the debate from very early on, with the United States Trade Representative (USTR) writing a letter to South Africa's United Nations representative in April 1997 querying South Africa's implementation of TRIPS and raising questions about compulsory licensing. By the time the amendment Bill was before parliament, US opposition was already evident; the US embassy in Pretoria presented the US government's views at a parliamentary hearing on the proposed amendments, while the US ambassador to South Africa made frequent public and private statements against the legalization of parallel imports.

Within two months of the amendment Act's adoption, the Pharmaceutical Research and Manufacturers of America (PhRMA) 
requested the USTR to designate South Africa a priority country under section 301 of the United States Trade Act of 1974 because "South Africa has become a 'test case' for those who oppose the US government's long-standing commitment to improve the terms of protection for all forms of American intellectual property, including pharmaceutical patents" (Consumer Project on Technology, 1999). Bristol-Myers Squibb (BMS) specifically complained about South Africa's decision to permit registration of a generic form of the cancer drug Paclitaxel (BMS brand name Taxol), an issue which the USTR took up during a WTO Trade Policy Review of South Africa a year later in Geneva. One month later, on May 1, 1998, the USTR put South Africa on the Special 301 Watch List. In June 1998, the Clinton administration announced that four items for which South Africa had requested preferential tariff treatment under the Generalized System of Preferences program would be put on hold until adequate progress was achieved in the protection of intellectual property rights in South Africa. At the end of October 1998, the United States Congress passed an omnibus appropriations Bill containing provisions cutting off US aid to the South African government pending a Department of State report outlining its efforts to "negotiate the repeal, suspension, or termination of section 15(c) of South Africa's Medicines and Related Substances Control Amendment Act No. 90 of 1997.”

The local response to the Medicines Act was led by the Pharmaceutical Manufacturers' Association of South Africa, which filed suit on behalf of forty-two parties, including local companies, subsidiaries of transnational corporations, and the multinational corporations themselves, challenging the constitutionality of the 1997 amendment to the Medicines Act. They made a number of constitutional claims but argued most specifically that the Act's provisions, which empower the government to determine the extent to which rights granted under a patent in South Africa shall apply, and which allow the Minister of Health to prescribe conditions for the supply of more affordable generic medicines, together deprived owners of intellectual property in the affected pharmaceutical products and thus of their constitutionally protected property rights.

Significantly, the domestic litigation initiated in this case, facilitated by the financial resources of the multinational corporations, took on a form unique in the South African context. The plaintiffs engaged a major private law firm, and state attorneys soon found themselves completely snowed under with the volume of filings and alternative 
lines of attack (author's interview, 1999). Not only did the plaintiffs initiate the litigation with a request for an interim interdict preventing the law from being implemented, they soon followed with a series of claims in alternative fora - to the Public Protector and the Competition Board - respectively challenging government statements about the high cost of drugs and calling for an inquiry into an alleged anti-competitive attempt by pharmaceutical distributors to create a joint company to engage in the parallel importation allowed under the Act.

In a notice of motion filed in the High Court of South Africa (Transvaal Provincial Division) in Pretoria on February 18, 1998, the plaintiffs articulated an extraordinary array of claims against the Act's validity. In addition to asserting that the Act violated their patent rights as well as South Africa's legally incorporated international obligations under TRIPS, the plaintiffs claimed that the powers granted the Minister of Health amounted to an unconstitutional delegation of legislative authority to the executive because it failed to set out policy considerations or guidelines that would limit the Minister's power. The plaintiffs also charged that various provisions of the amendment Act were unconstitutional as they violated the basic values and principles governing public administration included in section 195 of the Constitution. As if this was not enough, the plaintiffs then argued in the alternative that the Act conflicted with the legislature's constitutional obligations to take into consideration the recommendations made to the Portfolio Committee on Health and the Select Committee on Social Services in the National Council of Provinces South Africa's second chamber - requesting in the process that the legislature transmit to the Constitutional Court a transcript of all the proceedings on the Bill which preceded the passage of the Act. In her founding affidavit, M.T. Deeb, Chief Executive Officer of the Pharmaceutical Manufacturers Association, argued that section 15C was in conflict with the TRIPS agreement and went so far as to claim that "Parliament ought not to have made a law which is in conflict with South Africa's international obligations" (Deeb 1998a:para. 10.2.5).

This linking of the domestic constitutional claim with international trade issues continued when in a supplementary affidavit to the plaintiff's amended particulars of claim filed on July 23, 1998, Deeb argued that the USTR's placing of South Africa on the Special 301 Watch List "demonstrates that the provisions in the Amended Act which affect intellectual property are seen to be at least potentially in conflict with 
South Africa's international obligations and hence I submit that it cannot be regarded as being in the public interest as it may lead to the imposition of sanctions against this country and in fact may already have led to an undermining of investor confidence in South Africa" (Deeb 1998b:para. 20.6).

\subsection{BALANCING INTERNATIONAL COMMITMENTS AND FORA}

This threat of wider economic repercussions highlights the conflict between the domestic initiative to reduce drug prices and the global environment in which the policy was reflected. It is also important to recognize that even at the international level there are often tensions between the approaches taken by different government departments in their pursuit of different policies. While the 1997 amendment put South Africa into a direct bilateral trade conflict with the United States, these tensions were not confined to the trade arena but also surfaced at the World Health Assembly (WHA, the governing body of the $\mathrm{WHO}$ ) where South Africa was active in trying to reshape the debate over patent protection for pharmaceuticals. At the same time, South Africa's leadership in the WHA was in stark contrast to the government's unilateral decision not to implement the law - pending further legal proceedings - and the growing policy conflict over the government's response to HIV/AIDS, which included questioning the very biomedical basis of the epidemic. Here the law may be seen to be simultaneously facilitating, delaying, and providing a space for different players to achieve a variety of goals in their struggles: to gain access to affordable medicines; to further particular economic policies; or to protect their property interests.

At the end of April 1999, the USTR scheduled an "out-of-cycle" review for South Africa under Special 301, arguing that South Africa's barriers to trade included: parallel imports; compulsory licensing; registration of generic forms of Taxol; and taking a leading role at the World Health Assembly. According to the USTR: "During the past year, South African representatives have led a faction of nations in the World Health Organization (WHO) in calling for a reduction in the level of protection provided for pharmaceuticals in TRIPS" (Consumer Project on Technology, 1999). Thus, from the perspective of the USTR, the problem was not only the protection of patent rights in South Africa but also the position South Africa was taking in the 
international debate over TRIPS. Although it is broadly understood that the TRIPS agreement introduced a new set of minimum standards for the protection of intellectual property rights, there remained wide disagreement as to the meaning of the embedded exceptions to those rights. More significantly, the broad language of the exceptions contained in TRIPS meant that the degree of legal uncertainty remained broad, allowing member states to assert very different interpretations.

In this context, the $\mathrm{WHO}$ began questioning the relationship between the new international trade regime and its own mandate to promote world health. In January 1998, just over a month after the adoption of the new South African law allowing parallel importation, the Executive Board of the WHA recommended the adoption of the "Revised Drug Strategy," calling upon member states to "ensure that public health interests are paramount in pharmaceutical and health policies," as well as "to explore and review their options under relevant international trade agreements, to safeguard access to essential drugs." In May 1998, when the WHA began discussing the recommendation at its meeting in Geneva, the proposal came under heated attack from the developed countries including the US, the EU, and Japan. Supporting the proposals and leading the negotiations for the African countries was Dr. Olive Shisana from the South African Ministry of Health.

Although action on the resolution was initially deferred, a bitter conflict erupted over the strategy. An Ad Hoc Working Group of fiftynine countries met in October 1998 with South Africa and the United States representing the polar opposite positions. South Africa advocated for a strong public health statement while the United States represented the pharmaceutical industry's point of view (Consumer Project on Technology 1999). In January 1999, the WHA Executive Board met and approved the Revised Drug Strategy in the course of which South African health official, Dr. Desmond Johns, made comments which emphasized the strategy's openness to the parallel importation and compulsory licensing of pharmaceuticals. This interpretation was in conflict with the understanding of US officials and PhRMA who had a diametrically opposite interpretation of these developments (Consumer Project on Technology 1999).

Shaping the interpretation and understanding of the scope of internationally recognized intellectual property rights as well as the exceptions to them, takes place simultaneously in different settings. These include various international fora, in bilateral trade negotiations and conflicts, as well as in domestic legal arenas. This plethora of 
opportunities to pursue particular goals presents a clear advantage to those nations, industries, and organizations with the resources to participate at every level; however it also provides a differentiated arena in which coalitions of developing countries, NGOs, and other actors may productively intervene. The emergence and sustainability of these coalitions is, however, not preordained. In the struggle over access to affordable medicines it was the devastating impact of the HIV/AIDS pandemic in sub-Saharan Africa that provided the impetus for solidarity among a range of activist and policy-oriented organizations including: Act-Up and the Consumer Project on Technology in the United States; MSF, Oxfam and the South Centre in Europe; and the Treatment Action Campaign in South Africa. These interventions eventually led to a coordinated challenge from African member states in the TRIPS Council which later included other developing or newly industrializing countries at the WTO.

\subsection{SOCIAL MOBILIZATION AND A CHANGING TRADE REGIME}

The debate over intellectual property and trade underwent a dramatic shift from the beginning of 1999. In response to popular pressure from AIDS activists the Congressional Black Caucus began to link international HIV/AIDS policy and the question of trade disputes involving compulsory licensing, parallel imports, and other intellectual property issues. In February 1999, Representative Jesse Jackson Jr. introduced House Resolution 772, the "Hope for Africa Bill." Section 601 of the Bill proposed cutting off funding to any department or agency of the US government that sought "through negotiation or otherwise, the revocation or revisions of any sub-Saharan African intellectual property or competition law or policy that is designed to promote access to pharmaceuticals or other medical technologies," as long as those laws complied with TRIPS.

Two months later, in April 1999, several hundred protestors in downtown Washington DC demonstrated support for the Hope for Africa legislation and for compulsory licensing for HIV/AIDS and other essential medicines. Act-Up, a prominent US organization with a long history of activism on the issues of HIV/AIDS, called upon the US Department of Health and Human Services to give the WHO and foreign governments the right to use US government use rights in patents obtained as a result of federally funded research. Within two 
months, HIV/AIDS activists began a campaign to disrupt Vice President Gore's presidential election campaign to draw attention to US trade sanctions against South Africa and Thailand. These protests had an immediate effect. When Representative John Mica held hearings in Congress on US trade policy and the global AIDS crisis, Joseph Papovich from the USTR testified that the USTR no longer objected to parallel importing or compulsory licensing of pharmaceutical drugs in South Africa, if TRIPS compliant.

Finally, despite three years of needless delay by the government's lawyers, the South African case brought by the pharmaceutical companies against the government came to court in Pretoria and was withdrawn after the court accepted the intervention of the Treatment Action Campaign. The TAC had been demanding that the government provide access to medicines for both the treatment of HIV/AIDS-related opportunistic infections and to retrovirals for pregnant women and their newborn babies, but now sided with the government by arguing that the pharmaceutical industry was blocking attempts to reduce the prices of medicines needed to save the lives of those infected with HIV. Although the government remained resistant, even after the withdrawal of the case, to providing the drugs through the public health system (insisting that the case was not about HIV/AIDS drugs), it remains true that it was the public relations impact of the claim that the pharmaceutical companies were attempting to deny access to these drugs to the millions of HIV-positive South Africans that forced the hand of the companies. Not only did the companies concede that the law did not violate either the South African Constitution or TRIPS, they also agreed to pay the government's legal costs. The government, on the other hand, responded by arguing that they understood the new law as allowing for the parallel importation of patented drugs, but not necessarily the compulsory licensing of patented drugs, thus relieving the industry of one of its major concerns.

On September 17, 1999, the USTR announced that South Africa had agreed to implement the Medicines Act in a manner consistent with its obligations under the rules of the WTO "enabling us to set aside this issue from our bilateral trade agenda." Just over a week before, PhRMA had announced the suspension of the lawsuit brought against implementation of the Medicines Act in South Africa. Furthermore, officials at the office of the USTR said that they were now considering removing South Africa from the Special 301 Watch List. From the South African side there was a commitment to revisit the Act, 
although it was predicted that it would be some time before the government implemented the law.

The impact of these developments were not limited to South Africa. After Congress failed to enact section 601 in the Hope for Africa Bill, President Clinton issued an executive order on May 10, 2000, stating that in "administering sections 301-310 of the Trade Act of 1974, the United States shall not seek, through negotiation or otherwise, the revocation or revision of any intellectual property law or policy of a beneficiary sub-Saharan African country, as determined by the President, that regulates HIV/AIDS pharmaceuticals or medical technologies if the law or policy of the country: (1) promotes access to HIV/ AIDS pharmaceuticals or medical technologies for affected populations in that country; and (2) provides adequate and effective intellectual property protection consistent with the ... TRIPS Agreement." While it would seem that a partial resolution to the direct conflict between the South African and the US governments had been found, the international legal regime established under TRIPS remained uncertain.

\subsubsection{The Doha Declaration on TRIPS and public health}

In dire need of success the WTO was able to declare the launching of a new round of trade negotiations at the end of its ministerial conference on November 14, 2001. An essential ingredient was the issuing of a separate declaration on TRIPS and public health. Despite concerted opposition from multinational pharmaceutical corporations and a group of developed countries led by the United States, Switzerland, and Japan, the 140 trade ministers gathered in Doha, Qatar, agreed that the TRIPS agreement "does not and should not prevent members from taking measures to protect public health ... [and] that the agreement can and should be interpreted and implemented in a manner supportive of WTO members' rights to protect public health and, in particular, to promote access to medicines for all." At first glance, the developing world gained a major success. Not only is this interpretation extended to all aspects of public health, not just pharmaceuticals, but it also emphasizes the need to interpret the WTO agreements in more holistic ways. In essence, it accepts that an interpretation reducing barriers to free trade is not automatically the sole or correct understanding of the agreements.

Despite their opposition to a broad public health exception, their own threats to override Bayer's Cipro patent - in response to the mailed 
anthrax attacks after September 11, 2001 - completely undercut the claims of the United States and Canada that stronger patent protection was the most effective means of securing access to required medicines. With their prior arguments severely compromised and with no other effective means of addressing the ongoing HIV/AIDS pandemic, accepting the demands of developing countries became the easiest way to save the talks. Addressing what had been an intense debate within the TRIPS Council, the declaration specifically clarified the right of members: to grant compulsory licenses; to determine what constitutes a national emergency or other circumstances of extreme urgency; and that each member is free to establish its own regime for the exhaustion of intellectual property rights. It also encourages developed countries to promote technology transfer to the least developed countries and extends the initial transition period for pharmaceutical products in these countries until January 1,2016. This understanding of the TRIPS agreement and its future implementation amounts to a major shift in the rhetoric about the protection of intellectual property rights, embracing as it does most of the positions of the developing world - with much of the language for the declaration coming directly from the proposal put forward by Zimbabwe on behalf of the Africa Group and other developing countries.

\subsubsection{Paragraph 6 of the Doha Declaration and the problem of capacity}

The Doha Declaration, with its broad interpretation of the TRIPS agreement and its future implementation, amounted to a major shift in the global intellectual property regime, yet, given the realities of pharmaceutical production and distribution, it did not go very far toward ensuring access to urgently needed HIV/AIDS-related medications. Despite acknowledging that many countries have "insufficient or no manufacturing capacities in the pharmaceutical sector" and therefore cannot make effective use of compulsory licensing, the declaration failed to accept the developing countries' interpretation that they have the right to grant a compulsory license to a producer in another country having manufacturing capacity in order to gain access to medicines. Instead, the Declaration instructed the TRIPS Council to find a solution to this issue and to report to the WTO General Council by the end of 2002. Without the capacity to produce under compulsory license or import generic equivalents of the necessary medications, the problem of access for the millions infected or suffering from life-threatening 
diseases in developing countries remained unresolved. It took the TRIPS Council a further twenty-one months, to late August 2003, to reach agreement on the problem of access to medicines for countries that do not have manufacturing capacity.

Heralded at first as the solution to the problem of lack of capacity, the pre-Canćun agreement has since been criticized for placing so many preconditions on its implementation as to make it unworkable. These limitations include the requirement of proof by a country that it does not have: (1) production capacity; (2) access to affordable medicines; and (3) an existing health emergency. Although the Canadian government is discussing changing Canadian law to make the export of medicines made under compulsory license possible, the international brand-name pharmaceutical industry has begun to raise questions about whether Canada is precluded from supplying these medicines under the NAFTA agreement. Furthermore, even the Canadian government seems to be limiting its proposals to drugs designed to address only HIV/AIDS, malaria, and tuberculosis, a restriction rejected by the developing countries and the pre-Canćun agreement.

Once again it seems that the question of access to essential medicines is being displaced by an assertion of prior legal commitments - the idea of pacta sunt servanda, in which concerns over the rights of patent holders and an interpretation of the TRIPS agreement as a contractual arrangement place notions of unrestricted trade before the health needs of millions of people around the world. While all participants in the debate deny any intention to restrict access, or even such an effect (IIPI 2000), it seems hard to deny that the failure to resolve this issue, since it was first raised by the international pharmaceutical industry in its 1997 case against the South African law which was implementing an essential drugs program, has in fact frustrated attempts to broaden access. Even if it is accepted that the TRIPS agreement initially failed to accommodate the complexities of a global health emergency such as HIV/AIDS, it is hardly unreasonable to suggest that the principle of changed circumstances, or rebus sic stantibus, brought about by both new understandings of the magnitude of the pandemic as well as the emergence of effective medicines to address it, should have been applied to interpretations of TRIPS in order to facilitate all attempts to address this exploding crisis. At the least, such an approach would justify the assertion of an Article 30 exception under the TRIPS agreement. Instead, there has been a constant emphasis upon the rather unique protection of private rights contained in TRIPS and a denial of the legal effect of the so-called soft law 
exceptions and principles of interpretation which are also part of international trade law, including TRIPS.

\subsubsection{The Treatment Action Campaign and the struggle for antiretroviral treatments}

The domestic struggle over access to affordable medicines in South Africa did not end with the government's victory in the case brought by the Pharmaceutical Manufacturers Association or the Doha Declaration. The next phase of legal activity, initiated by the Treatment Action Campaign (TAC) and given its impetus by the consolidation of a new broad-based social movement including TAC branches and the People Living with AIDS organization as well as support from the trade union movement and the communist party, included two legal challenges. The first challenged the government to provide mothers and their new-born babies access to Nevirapine, an antiretroviral which, when administered to both mother and child during birth and shortly thereafter, more than halved the rate of mother-to-child transmission of HIV. Secondly, the TAC brought a complaint before the Competition Board alleging that a number of the major pharmaceutical corporations had colluded in maintaining the high price of particular medicines. The impact of these two initiatives was to dramatically alter the debate over access to antiretroviral treatment and to set the stage for a major reduction in the price of medicines.

In the mother-to-child transmission (MTCT) case, the Constitutional Court essentially upheld a High Court decision requiring the government to provide mothers and new-born babies in public health facilities access to Nevirapine. Relying on the constitutional guarantee of a right to the progressive realization of access to health care services, the Constitutional Court argued that, under the circumstances, in which the cost of the drug and the provision of appropriate testing and counseling to mothers was less burdensome than the failure to provide Nevirapine, the government had a constitutional duty to expand its program beyond the eighteen test sites the health authorities had already planned.

In the second case, the TAC, pursuing its aim to lower drug prices and thus expand access to antiretroviral treatment, launched a complaint with the newly created Competition Commission against two of the major pharmaceutical corporations active in South Africa GlaxoSmithKline (GSK) and Boehringer Ingelheim - accusing them of engaging in excessive pricing of medicines. After the Commission 
found that the companies had colluded to fix prices, the companies reached an out-of-court settlement with the government which included granting at least three generic pharmaceutical companies voluntary licenses on three major antiretrovirals, thus allowing more competition into the market and lowering the price of the drugs in the South African market. Despite these dramatic interventions and legal victories, the problem of access remains unsolved. For the majority of HIV-infected South Africans, even the reduced price of the drugs on the private market is unaffordable and until the government manages to roll out the public sector program they will continue to be denied access.

\subsection{CONCLUSION}

After twenty years, the HIV/AIDS pandemic has finally been recognized as a global health crisis, yet the debates over access to public goods which are essential to defeating this scourge continue to be shaped less by principles of public health than by concerns over unrestricted trade and intellectual property rights. Within the legal field, the claims of the international patent-based pharmaceutical corporations are framed as rights to property, while the claims of NGOs and developing country governments seeking access to affordable medicines are characterized as legal exceptions to free trade or as the soft law contained in general preambular statements. These formal legal distinctions, based upon the interpretation of international agreements created in a context of asymmetrical power, are now relied upon to delay and avoid recognizing the urgent needs of those whose very lives and futures are at stake. But the emergence of a new social movement, both domestically and transnationally, based on a new solidarity which places public needs over corporate claims of property rights has begun to shift the balance of power (Santos 2002).

Driven by this new solidarity - which brings together a unique yet loose alliance of health, human rights, and development activists together with some governments and parts of the pharmaceutical industry, particularly generic producers - the international intellectual property and trade regime has begun to change. First, there is a new acceptance of a human rights perspective, in which the health impact of any particular legal option or interpretation is an equally legitimate consideration in evaluating the validity of any particular intellectual property or trade rule. Secondly, there is recognition that both health 
and human rights considerations are an essential corrective to the present distinction between so-called hard law obligations and soft law principles or commitments. Thirdly, the acceptance of these approaches to the interpretation of the TRIPS agreement may facilitate access to medicines by emboldening private investors to accept compulsory licenses or other exemptions as sufficient to secure their needed investments in generic production. Finally, such an approach should also provide developing countries with a means to justify decisions to privilege policies securing access to medicines over concerns about their international trade commitments or threats from patent holders. Instead of relying on thin strands of legal flexibility, NGOs, international organizations, and governments attempting to address the global HIV/AIDS pandemic might look to the building of this new, multifaceted, and complex solidarity to assert a human rightsbased interpretation of the international trade and intellectual property regime - one which places public health ahead of property claims.

\section{References}

African National Congress. 1994a. "A National Health Plan for South Africa." Prepared by the ANC with the technical support of $\mathrm{WHO}$ and UNICEF, May.

1994b. "RDP White Paper Discussion Document." September.

Bond, Patrick. 1999. "Globalization, Pharmaceutical Pricing and South African Health Policy: Managing Confrontation with US Firms and Politicians." International Journal of Health Services 29(4):765.

Consumer Project on Technology. 1999. Cptech, Appendix B: Time-Line of Disputes over Compulsory Licensing and Parallel Importation in South Africa, http://www.cptech.org/ip/health/sa/sa-timeline.txt, August 5, 1999. Deeb, M. T. 1998a. Founding Affidavit, February, 18 High Court of South Africa.

1998b. Supplementary Affidavit by M. T. Deeb, July, 23 High Court of South Africa.

Department of Health, "National Drug Policy for South Africa." January.

International Intellectual Property Institute. 2000. Patent Protection and Access to HIV/AIDS Pharmaceuticals in Sub-Saharan Africa. Washington, DC: International Intellectual Property Institute.

Klug, Heinz. 2000. Constituting Democracy: Law, Globalism and South Africa's Political Reconstruction. Cambridge: Cambridge University Press.

Minister of Health v. Treatment Action Campaign 2002 (5) SA 721 (CC). Moy, Carl R. 1993. "The History of the Patent Harmonization Treaty: Economic Self-Interest as an Influence." John Marshall Law Review 26:457 
Ryan, Michael. 1998. "Knowledge Diplomacy: Global Competition and the Politics of Intellectual Property.” Washington, DC: Brookings Institution. Santos, Boaventura de Sousa. 2002. Toward a New Legal Common Sense: Law, Globalization and Emancipation. London: .Butterworths.

Sell, Susan K. 2003. Private Power, Public Law: The Globalization of Intellectual Property Rights. Cambridge: Cambridge University Press.

Soobramoney v. Minister of Health, KwaZulu-Natal 1997 (12) BCLR 1696 (CC).

WTO. 1994. Final Act Embodying the Results of the Uruguay Round of Multilateral Trade Negotiations. 